\title{
ANALYZING THE SOCIAL FACTORS AFFECTING AVIATION DEVELOPMENT IN COUNTRIES BY CREATING A MIXED CURVILINEAR REGRESSION MODEL
}

DOI: 10.17261/Pressacademia.2021.1381

JBEF- V.10-ISS.1-2021(3)-p.24-35

\section{Gokhan Koc}

TAV Technologies, R\&D Department, Sarıer, İstanbul, Turkey. gokhan.koc@tav.aero, ORCID: 0000-0001-7433-2356

\begin{tabular}{l} 
Date Received: January 2, $2021 \quad$ Date Accepted: March 12, 2021 \\
\hline To cite this document \\
Koc, G. (2021). Analyzing the social factors affecting aviation development in countries by creating a mixed curvilinear regression model. Journal \\
of Business, Economics and Finance (JBEF), V.10(1), p.24-35 \\
Permanent link to this document: $\underline{\text { http://doi.org/10.17261/Pressacademia.2021.1381 }}$ \\
Copyright: Published by PressAcademia and limited licensed re-use rights only.
\end{tabular}

\section{ABSTRACT}

Purpose- The objective of this study is to determine the social factors of countries that are effective in the development of aviation and to measure their effects on aviation development by creating a mixed curvilinear regression model.

Methodology- The study is started with a literature review to determine the possible effective social factors on aviation development and then a mixed curvilinear regression model is developed to measure the weights of these factors.

Findings- 15 different social factors were examined to produce inputs for the regression model. Feature selection of regression model is examined and the reasons for eliminating the features were investigated. The weights of the social factors included in the regression model relative to each other was measured.

Conclusion- Aviation has been battling the devastating impact of the Covid-19 outbreak since the beginning of 2019. Now, the importance of every passenger, the value of the money spent on investments and impact of airport efficiencies have increased to a level which is never touched before. This study is carried out to enrich the research conducted before investments in the aviation industry.

Keywords: Curvilinear regression, mixed regression, social factors, aviation, air travel per capita JEL Codes: L91, L83, O57

\section{INTRODUCTION}

After the spread of the Covid-19 pandemic, international tourism activities in the entire world have decreased significantly and the number of daily flights has dropped more than half because of travel restrictions and lockdowns (Gössling et al., 2005). Airports and airlines accelerated their investments in touchless passenger journeys (Serrano and Kazda, 2020; Tabares, 2021) however according to some researches (Gudmundsson et al., 2021; Curley et al., 2020) aviation will not recover to pre-crisis levels until 2023. Therefore, determining the effective social factors of aviation development and the weights of these factors could provide insight for stakeholders of the industry to direct their investments. A series of studies have been reviewed to determine possible effective social factors and details of findings are shared in Section 2.

The entire study is conducted across the country's 2018 statistics to prevent the covid-19 effect from distorting the results. In this study, social factor scores of countries are placed as inputs and air travel per capita scores of countries are placed as the output of regression models. Also, for each determined social factor, country scores are compared with air travel per capita scores to measure the linear correlations between factors and air travel performances. After the linear correlation measurement, it is seen that there is no linear correlation between some of the factors and air travel per capita scores. So, polynomial normalization is applied to these factors to increase the linear correlation score between these factors and air travel per capita scores. After the normalization phase, various linear regression models formed with a different combination of factors and adjusted $\mathrm{R}$ Squared 
values for the models, and $p$ values for the factors were measured with real air travel per capita scores. At the end of this process, it is seen that some factors do not have a significant effect on predicting air travel per capita scores, and these factors are removed from the final regression model. In the last stage of the study, separately for each factor, scores of the countries were increased by $10 \%$ and the regression model has generated new air travel per capita predictions. Regression model outputs of real inputs and increased inputs are compared so the weights of factors according to the generated regression model are determined.

\section{LITERATURE REVIEW}

According to the article (Schafer and Victor, 2000), years of changes in transportation trends pointing out that air travel as a transportation option will keep rising in the future because people, in general, tend to travel faster and more comfortably with the increase in their income. Also, another research (Ishutkina and Hansman, 2011) correlation above 0.9 measured between GDP and the number of passengers for the entire world between the years 1970 and 2005. Therefore, "GDP per Capita" was added to this study as a possible effective social factor on aviation development and input for regression models.

In another article (Tayco, 2013), World Tourism Organization Travel Reports are evaluated with countries Global Peace Index scores and as a result, it is seen that tourists, in general, are considering peace and safety level of the destinations before they travel. According to the Institute for Economics \& Peace, Global Peace Index scores of countries are calculated with measuring objectives such as well-functioning government, equitable distribution of resources, free flow of information, good relations with neighbors, high level of human capital, acceptance of the rights of others, low levels of corruption, sound business environment (Index, 2018). Global Peace Index could affect aviation development but people are not traveling just for leisure but also for business activities. According to several articles (Hassan and Basit, 2018; Corcoran and Gillanders, 2015) Ease of Doing Business scores has a high level of correlation with foreign direct investments and business trip counts relatively. According to the World Bank, Ease of Doing Business scores of countries are calculated with measuring objectives such as starting a business, dealing with construction permits, getting electricity, registering property, getting credit, protecting minority investors, paying taxes, trading across borders, enforcing contracts, resolving insolvency (World Bank, 2017). Therefore, "Global Peace Index Score" and "Ease of Doing Business Score" have been added to this study as possible effective social factors on aviation development and inputs for regression models.

Another important social factor is mentioned as travel distance because passengers are considering the time that they will spend on the flight and distance-related flight prices (Chen, 2018). Other factors such as the weakness of the transport network inside the country and customs regulations may also affect the air travel per capita scores of the countries. Therefore, in this study, the "Logistic Performance Index" score (LPI) of World Bank, which generates country LPI scores by evaluating custom performances, infrastructure sufficiency, international shipments, logistic quality and competence, tracking, tracing, and timeliness performances, is used as an input (Arvis et al., 2018). Also, for the same reasons, "Visa-Free Destination Count" and "Neighbor Count" of countries are included in the study as inputs because $60 \%-65 \%$ of the daily flights are being operated between different countries (Oxley, 2018). Travelers tend to choose visa-free destinations (Bangwayo-Skeete and Skeete, 2017) and culturally and physically close countries (Debski and Nasierowski, 2017).

It is accepted as one of the social factors affecting the development of aviation in cultural development such as financial development. It has been determined that the higher the number of immigrants and the proportion of women immigrants in a country could be used as a performance indicator for measuring the financial prosperity and cultural diversity of that country (Taylor, 2006). Immigrants who have reached a sufficient income level are flying to their own countries and visit their relatives and friends at certain intervals. For example, more than 5 million Turkish Citizen living outside of Turkey and their relative visits are increasing the number of flights in cities that are not tourist cities during the summer months (Özpolat, 2012; İslamoğlu et al., 2014). However, for some cases, the proportion of women immigrants doesn't mean that country is developed in gender equality. Women are immigrating to some countries where women's rights are not given yet, but financial development is above average (Silvey, 2006). There are also some other parameters determined to measure cultural development in a country such as education and technology usage levels of citizens (Woolman, 2001; Calhoun et al., 2002). Because of all these findings, "Gender Inequality Index Score", "Percentage of International Migrants", "Emigration Ratio", "Education Index Score", "IDI Index Score" of countries has been added to this study as possible effective social factors on aviation development and inputs for regression models. Gender Inequality Index Score is being calculated by the United Nation Development Program and measures gender inequalities in three important aspects of human development; reproductive health, empowerment, and economic status (Gaye et al., 2010). Education Index Score is also being measured by United Nations Development Program and calculated by using mean years of schooling and expected years of schooling (Nguefack-Tsague et al., 2011). However, IDI Index Score is published by the United 
Nations International Telecommunication Union based on internationally agreed information and communication technologies (ICT) indicators (Kwan, 2007; Ayanso and Lertwachara, 2011).

According to DATASET2050 Project Reports, there is a correlation between household size and air travel count of countries because it is seen that households without children are those with the highest disposable income (Cook et al., 2017). Also, in the same report, it is clear that the percentage of urban population ratio and population ages of 15-64 has a relation with air travel per capita ratios of countries. Therefore, "Household Size Ratio For 6+ (\% of the total population)", "Urban population (\% of the total population)", "Population Ages 15-64 (\% of the total population)" of countries have been added to this study as possible effective social factors on aviation development and inputs for regression models. Also, "Global Weight of Cross Border Financial Services per Capita" has the potential to be an effective social factor because it's seen that air travel per capita rates of some island countries with high financial privacy appeared to be high (Zheng, 2020).

Throughout the literature review, 15 different possible social factors can affect people's flight tendencies detected. Whether or to what extent these social factors affect people's flight tendencies is evaluated in detail in the following sections.

\section{DATA AND METHODOLOGY}

\subsection{Feature (Input) Preparation}

First, the social factor scores that can affect the aviation development of the countries determined in the literature review section were collected from appropriate sources as indicated in Table 1. For some countries, there were no scores in one or more data sources, so these countries are not included in the regression model. Also, Ireland, Switzerland, UAE, Qatar, and Denmark are defined as outliers because no successful results were obtained with the values of these countries in any input configuration.

Since the population numbers of the countries are different, air travel per capita values are used despite total air travel counts when analyzing the effects. In other words, the output of the regression model is the air travel per capita ratios of countries. Air travel per capita ratios of 2018 are gathered from The World Bank databases.

Table 1: Inputs (Social Factors) for Regression Model

\begin{tabular}{|c|c|c|c|c|}
\hline No & Input Name & $\begin{array}{c}\text { Input } \\
\text { Variable }\end{array}$ & $\begin{array}{l}\text { Variable after } \\
\text { Normalization }\end{array}$ & Data Source \\
\hline 1 & Ease of Doing Business Score & $x_{1}$ & $x_{n 1}$ & The World Bank, 2018 \\
\hline 2 & Gender Inequality Index Score & $x_{2}$ & $x_{n 2}$ & The United Nations, 2018 \\
\hline 3 & GDP Per Capita (current US\$) & $x_{3}$ & $x_{n 3}$ & The World Bank, 2018 \\
\hline 4 & Global Peace Index Score & $x_{4}$ & $x_{n 4}$ & $\begin{array}{l}\text { The Institute for Economics \& Peace, } \\
2018\end{array}$ \\
\hline 5 & Percentage of International Migrants & $x_{5}$ & $x_{n 5}$ & $\begin{array}{l}\text { Migration Data Portal, Total of last } 40 \\
\text { years }\end{array}$ \\
\hline 6 & Emigration Ratio (\% of total population) & $x_{6}$ & $x_{n 6}$ & $\begin{array}{l}\text { Migration Data Portal, Total of last } 40 \\
\text { years }\end{array}$ \\
\hline 7 & $\begin{array}{l}\text { Household Size Ratio For } 6+\text { (\% of total } \\
\text { population) }\end{array}$ & $x_{7}$ & $x_{n 7}$ & The United Nations, Newest Value \\
\hline 8 & Logistic Performance Index Score & $x_{8}$ & $x_{n 8}$ & The World Bank, 2018 \\
\hline 9 & Population Ages 15-64 (\% of total population) & $x_{9}$ & $x_{n 9}$ & The World Bank, 2018 \\
\hline 10 & Education Index Score & $x_{10}$ & $x_{n 10}$ & The United Nations, 2018 \\
\hline 11 & Urban population (\% of total population) & $x_{11}$ & $x_{n 11}$ & The World Bank, 2018 \\
\hline 12 & Visa Free Destination Count & $x_{12}$ & $x_{n 12}$ & The World Bank, 2018 \\
\hline 13 & Neighbor Counts & $x_{13}$ & $x_{n 13}$ & The World Bank, 2018 \\
\hline 14 & $\begin{array}{l}\text { Global Weight of Cross Border Financial Services } \\
\text { per Capita }\end{array}$ & $x_{14}$ & $x_{n 14}$ & Tax Justice Network, 2018 \\
\hline 15 & IDI Index Score & $x_{15}$ & $x_{n 15}$ & $\begin{array}{l}\text { International Telecommunication Union, } \\
2018\end{array}$ \\
\hline
\end{tabular}




\subsection{Input Linearization and Normalization}

After gathering all the input data, the linear correlation between the countries' air travel per capita rates and input values was measured. Polynomial normalization was applied to some of the inputs which has low linear correlation with air travel per capita ratios. Thus, the linear correlation between air travel per capita and inputs has been increased, as can be seen in Figure 1.

Figure 1: Correlations between Air Travel per Capita Ratios and Inputs Before and After Input Normalization

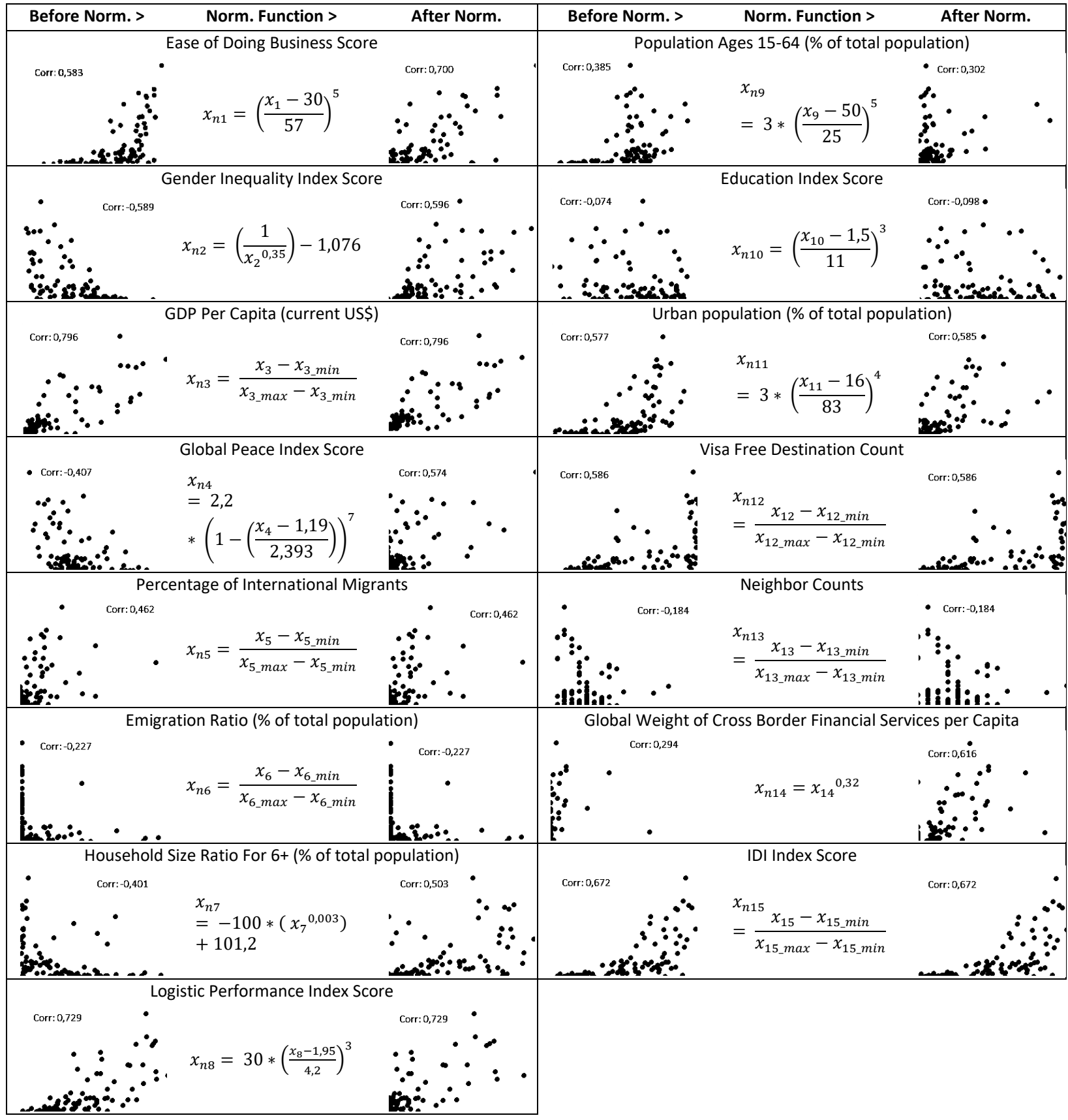


Ease of Doing Business Score, Global Peace Index, Household Size Ratio For 6+, Global Weight of Cross Border Financial Services per Capita had a strong polynomial correlation with air travel per capita ratios. Therefore, after polynomial normalization applied to these features, correlations are increased as is seen in Figure-1. GDP per Capita, Logistic Performance Index Score, IDI Index Score had a strong linear correlation with air travel per capita already so only stand normalization is applied on these features. Also, polynomial normalization has increased correlations of Urban Population, Gender Inequality Index Score, and Education Index Score slightly. However, there were also some features whose correlation could not be increased despite all the attempts such as Emigration Ratio, Neighbor Count, Percentage of International Migrants, Population Ages 15-64 (\% of the total population), and Education Index Score.

\subsection{Creating Regression Model with Modified Features}

After all the features have been modified, the search for the regression model that gives the most successful result with various feature combinations has begun. In the first test, a regression model is generated with all features and without constants. Adjusted $\mathrm{R}$ Square for first regression model is measured 0,841 and standard error is calculated 0,377 . Performance of first regression model is better than expectation but it is seen in Table 2 that P-Values of some features are higher than 0,2 .

Table 2: Regression Model Feature Results of First Test

\begin{tabular}{lcccccc}
\hline Modified Feature Variable & Coefficients & Standard Error & T Stat & P-Value & Lower 95\% & Upper 95\% \\
\hline Ease of Doing Business Score & 1,33 & 0,32 & 4,10 & 0,00 & 0,68 & 1,97 \\
\hline GDP Per Capita (current US\$) & 0,81 & 0,57 & 1,41 & 0,16 & $-0,33$ & 1,94 \\
\hline Global Peace Index Score & 0,28 & 0,15 & 1,93 & 0,06 & $-0,01$ & 0,57 \\
\hline Emigration Ratio (\% of total population) & $-0,39$ & 0,23 & $-1,71$ & 0,09 & $-0,85$ & 0,07 \\
\hline Household Size Ratio For 6+ & $-0,57$ & 0,25 & $-2,23$ & 0,03 & $-1,07$ & $-0,06$ \\
\hline Logistic Performance Index & 0,16 & 0,10 & 1,61 & 0,11 & $-0,04$ & 0,36 \\
\hline Population Ages 15-64 (\% of total population) & $\mathbf{0 , 1 9}$ & 0,09 & $\mathbf{2 , 1 9}$ & 0,03 & 0,02 & 0,37 \\
\hline Urban population (\% of total population) & $\mathbf{0 , 2 3}$ & 0,11 & $\mathbf{2 , 0 4}$ & 0,04 & 0,01 & 0,45 \\
\hline Gender Inequality Index Score (GII) & $\mathbf{- 0 , 0 5}$ & $\mathbf{0 , 2 1}$ & $\mathbf{- 0 , 2 5}$ & $\mathbf{0 , 8 0}$ & $-\mathbf{0 , 4 8}$ & $\mathbf{0 , 3 7}$ \\
\hline Percentage of International Migrants & $\mathbf{- 0 , 1 1}$ & $\mathbf{0 , 4 9}$ & $\mathbf{- 0 , 2 2}$ & $\mathbf{0 , 8 2}$ & $\mathbf{- 1 , 0 8}$ & $\mathbf{0 , 8 6}$ \\
\hline Education Index Score & $\mathbf{0 , 0 0}$ & $\mathbf{0 , 0 0}$ & $\mathbf{- 1 , 0 3}$ & $\mathbf{0 , 3 1}$ & $\mathbf{0 , 0 0}$ & $\mathbf{0 , 0 0}$ \\
\hline Visa Free Destination Count & $\mathbf{0 , 1 8}$ & $\mathbf{0 , 2 5}$ & $\mathbf{0 , 7 1}$ & $\mathbf{0 , 4 8}$ & $\mathbf{- 0 , 3 2}$ & $\mathbf{0 , 6 8}$ \\
\hline Neighbor Counts & $-0,31$ & $\mathbf{0 , 2 2}$ & $-1,42$ & $\mathbf{0 , 1 6}$ & $-0,75$ & 0,13 \\
\hline Global Weight of Cross Border Financial & $\mathbf{- 0 , 0 5}$ & $\mathbf{0 , 0 6}$ & $\mathbf{- 0 , 8 2}$ & $\mathbf{0 , 4 2}$ & $-\mathbf{0 , 1 6}$ & $\mathbf{0 , 0 7}$ \\
\hline IDI Index Score & $\mathbf{0 , 3 6}$ & $\mathbf{0 , 4 1}$ & $\mathbf{0 , 8 8}$ & $\mathbf{0 , 3 8}$ & $\mathbf{- 0 , 4 5}$ & $\mathbf{1 , 1 7}$ \\
\hline
\end{tabular}

After evaluating the results of the first test, all features with a P-Value higher than 0.2 were removed from the model and the second test is executed. In the second test, although many features were removed, the adjusted $\mathrm{R}$ square value of the model became slightly higher $(0,846)$ and the standard error is decreased to 0,371 . Thus, it was determined that the features extracted from the model did not benefit the model in predicting the number of passengers in countries. When Table 3 , which includes the feature results of the second test, is examined, it can be seen that the P-Values of all features except Neighbor Count are less than 0.15 .

Table 3: Regression Model Feature Results of Second Test

\begin{tabular}{lcccccc}
\hline Modified Feature Variable & Coefficients & Standard Error & T Stat & P-Value & Lower 95\% & Upper 95\% \\
\hline Ease of Doing Business Score & 1,50 & 0,28 & 5,30 & 0,00 & 0,94 & 2,07 \\
\hline GDP Per Capita (current US\$) & 0,69 & 0,44 & 1,56 & 0,12 & $-0,19$ & 1,57 \\
\hline Global Peace Index Score & 0,31 & 0,13 & 2,38 & 0,02 & 0,05 & 0,57 \\
\hline Emigration Ratio (\% of total population) & $-0,34$ & 0,21 & $-1,59$ & 0,11 & $-0,75$ & 0,08 \\
\hline Household Size Ratio For 6+ & $-0,44$ & 0,16 & $-2,77$ & 0,01 & $-0,76$ & $-0,12$ \\
\hline Logistic Performance Index & 0,15 & 0,09 & 1,67 & 0,10 & $-0,03$ & 0,33 \\
\hline Population Ages 15-64 (\% of total population) & 0,22 & 0,07 & 3,04 & 0,00 & 0,08 & 0,36 \\
\hline Urban population (\% of total population) & $\mathbf{0 , 2 6}$ & $\mathbf{0 , 0 8}$ & $\mathbf{3 , 1 8}$ & $\mathbf{0 , 0 0}$ & 0,10 & 0,43 \\
\hline Neighbor Counts & $\mathbf{- 0 , 2 5}$ & $\mathbf{0 , 1 9}$ & $\mathbf{- 1 , 3 1}$ & $\mathbf{0 , 1 9}$ & $\mathbf{- 0 , 6 2}$ & $\mathbf{0 , 1 3}$ \\
\hline
\end{tabular}


In the third and last test, the Neighbor Counts feature was removed from the model and a new regression model was created. Adjusted R Square is dropped 0,001 point and became 0,845 and standard error is increased 0,002 point became 0,373. Thus, it was determined that the Neighbor Count feature benefited the regression model in predicting the number of passengers of countries, but this benefit was not significant. When the table 4 containing the feature results of the model created with the test number 3 is examined, the coefficients of the modified features are seen.

Table 4: Regression Model Feature Results of Third Test

\begin{tabular}{lcccccc}
\hline Modified Feature Variable & Coefficients & Standard Error & T Stat & P-Value & Lower 95\% & Upper 95\% \\
\hline Ease of Doing Business Score & 1,51 & 0,29 & 5,29 & 0,000 & 0,94 & 2,08 \\
\hline GDP Per Capita (current US\$) & 0,82 & 0,43 & 1,92 & 0,059 & $-0,03$ & 1,68 \\
\hline Global Peace Index Score & 0,33 & 0,13 & 2,49 & 0,015 & 0,07 & 0,59 \\
\hline Emigration Ratio (\% of total population) & $-0,38$ & 0,21 & $-1,80$ & 0,076 & $-0,79$ & 0,04 \\
\hline Household Size Ratio For 6+ & $-0,52$ & 0,15 & $-3,48$ & 0,001 & $-0,82$ & $-0,22$ \\
\hline Logistic Performance Index & 0,13 & 0,09 & 1,47 & 0,146 & $-0,05$ & 0,31 \\
\hline Population Ages 15-64 (\% of total population) & 0,20 & 0,07 & 2,85 & 0,005 & 0,06 & 0,34 \\
\hline Urban population (\% of total population) & 0,24 & 0,08 & 2,97 & 0,004 & 0,08 & 0,40 \\
\hline
\end{tabular}

As seen in Table 4, P-Values of all modified features except Logistic Performance Index are well below 0.1 . As a result of that, the final regression model is formed as indicated in the equation:

$$
\begin{aligned}
& Y=1,51 *\left(\frac{x_{1}-30}{57}\right)^{5}+0,82 *\left(\frac{x_{3}-381,2}{62615,2}\right)+0,33 * 2,2 *\left(1-\left(\frac{x_{4}-1,19}{2,393}\right)\right)^{7}-0,38 *\left(\frac{x_{6}-0,001}{0,468}\right)-0,52 \\
& *\left(\left(-100 * x_{7}^{0,003}\right)+101,2\right)+0,13 * 30 *\left(\frac{x_{8}-1,95}{4,2}\right)^{3}+0,2 * 3 *\left(\frac{x_{9}-50}{25}\right)^{5}+0,24 * 3 \\
& *\left(\frac{x_{11}-16}{83}\right)^{4}
\end{aligned}
$$

\subsection{Performance of Final Regression Model}

After the regression model was created, all feature performances and entire model results were measured. When the residual plots in Figure 2 are examined, it is seen that the normalizations applied for the features result successful and the linear correlation between the modified features and air travel per capita is clear. Also, it is seen that there is not any point at widely varying distances from the lines. When standard residuals of countries are calculated it is seen that predictions for some countries are failed (Magnitude of Standard Residual > 2) more than others such as Belgium, Estonia, Greece, Lithuania, Latvia, Netherlands.

Figure 2: Residual Plots of Features

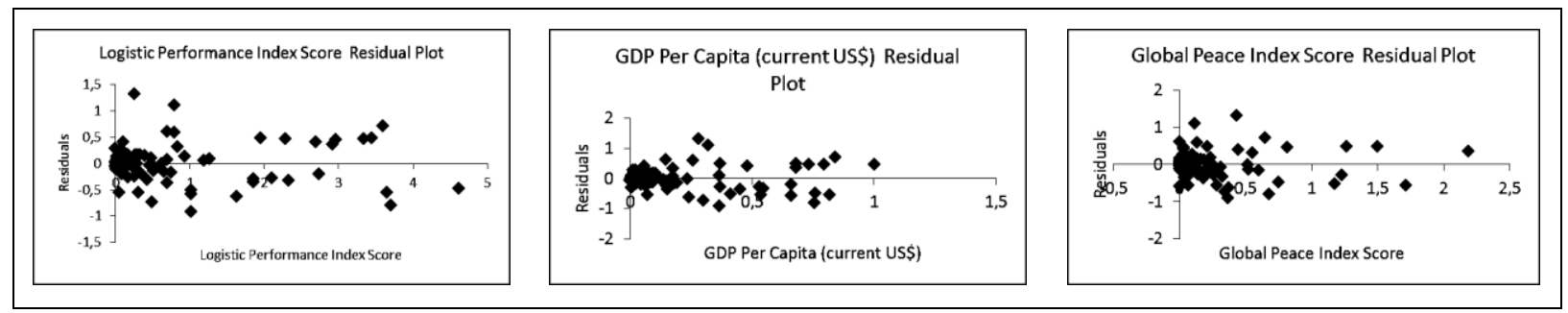




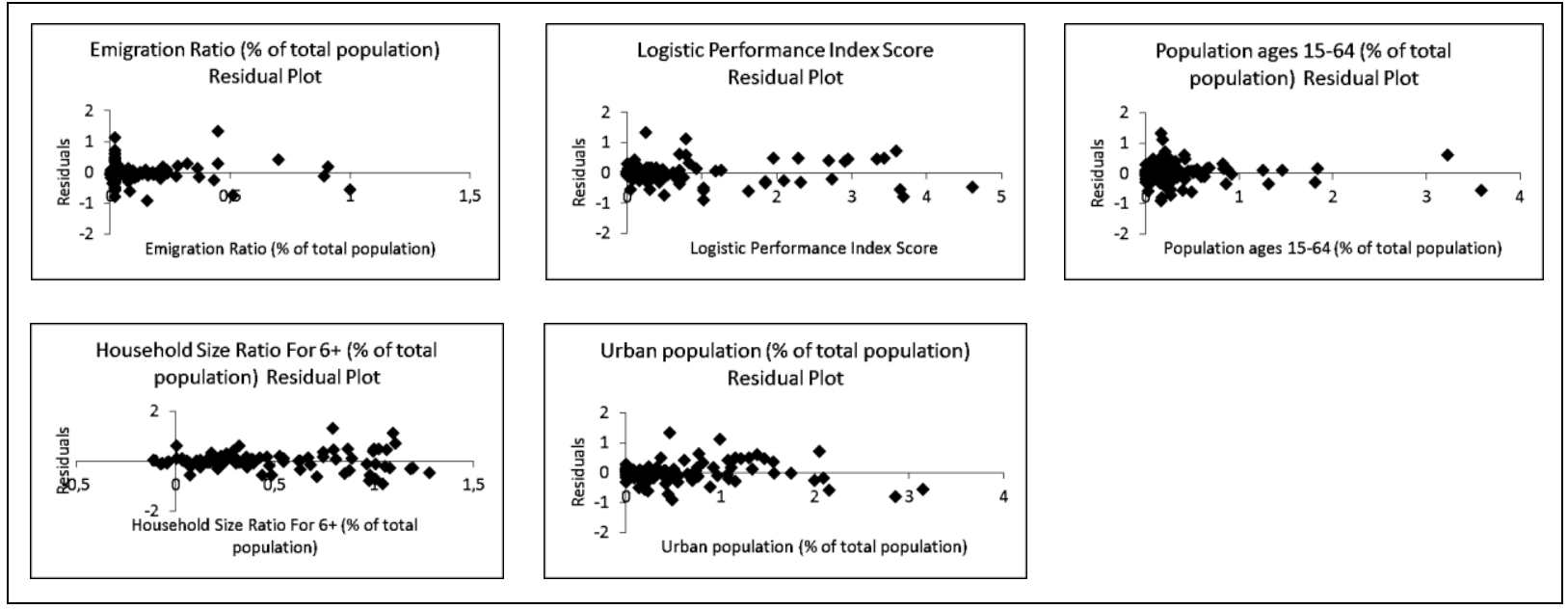

When the Line Fit Plots of Features in Figure 3 are examined, it is seen that the predictions and real values for all features are very close to each other.

Figure 3: Line Fit Plots of Features and Normal Probability Plot
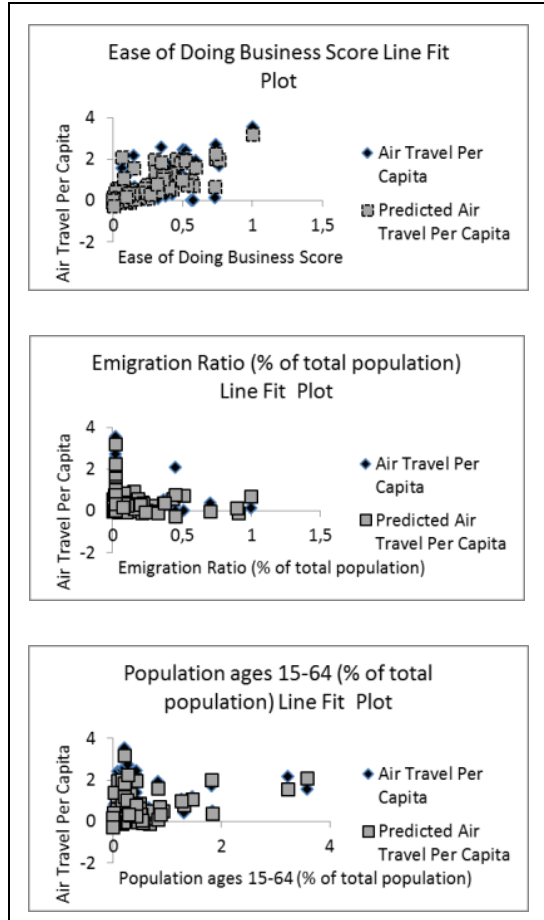
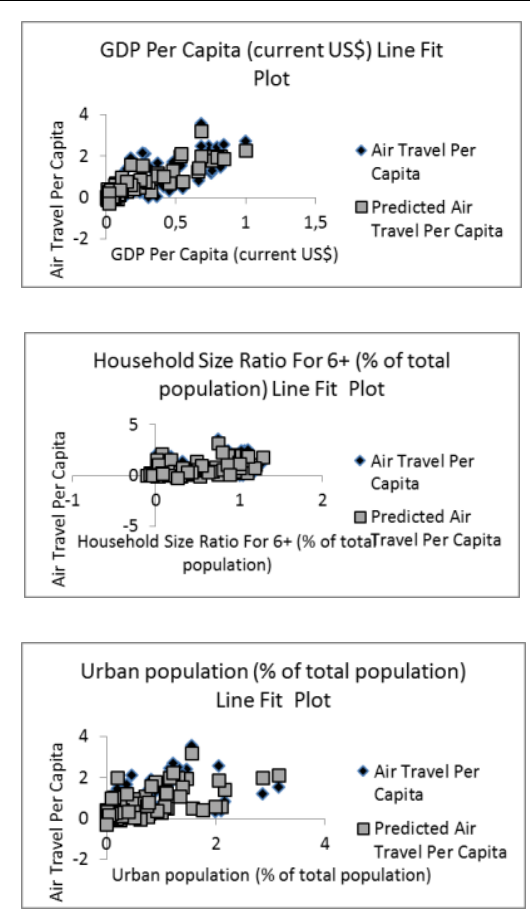

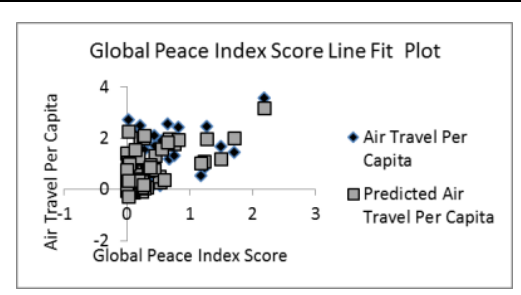

Logistic Performance Index Score Line Fit Plot
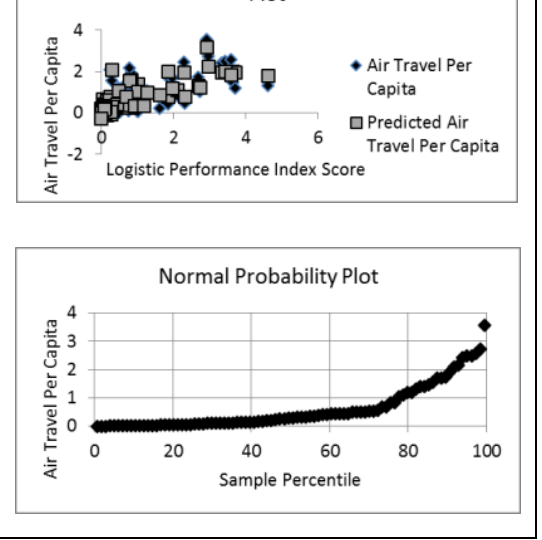

As is mentioned above; Prediction scored of Belgium, Estonia, Greece, Lithuania, Latvia, Netherlands are worse than other countries and it can also be seen easily in Figure 4. When these countries are accepted as an outlier and removed from the model, the adjusted R Square value of the regression model reaches 0.899 and the standard error decreases to 0.27 . However, the Pvalue of GDP per Capita increase to 0,163 and therefore these countries these countries were not excluded from the model.

\section{Figure 4: Predictions of Regression Model and Real Air Travel Per Capita Comparison}




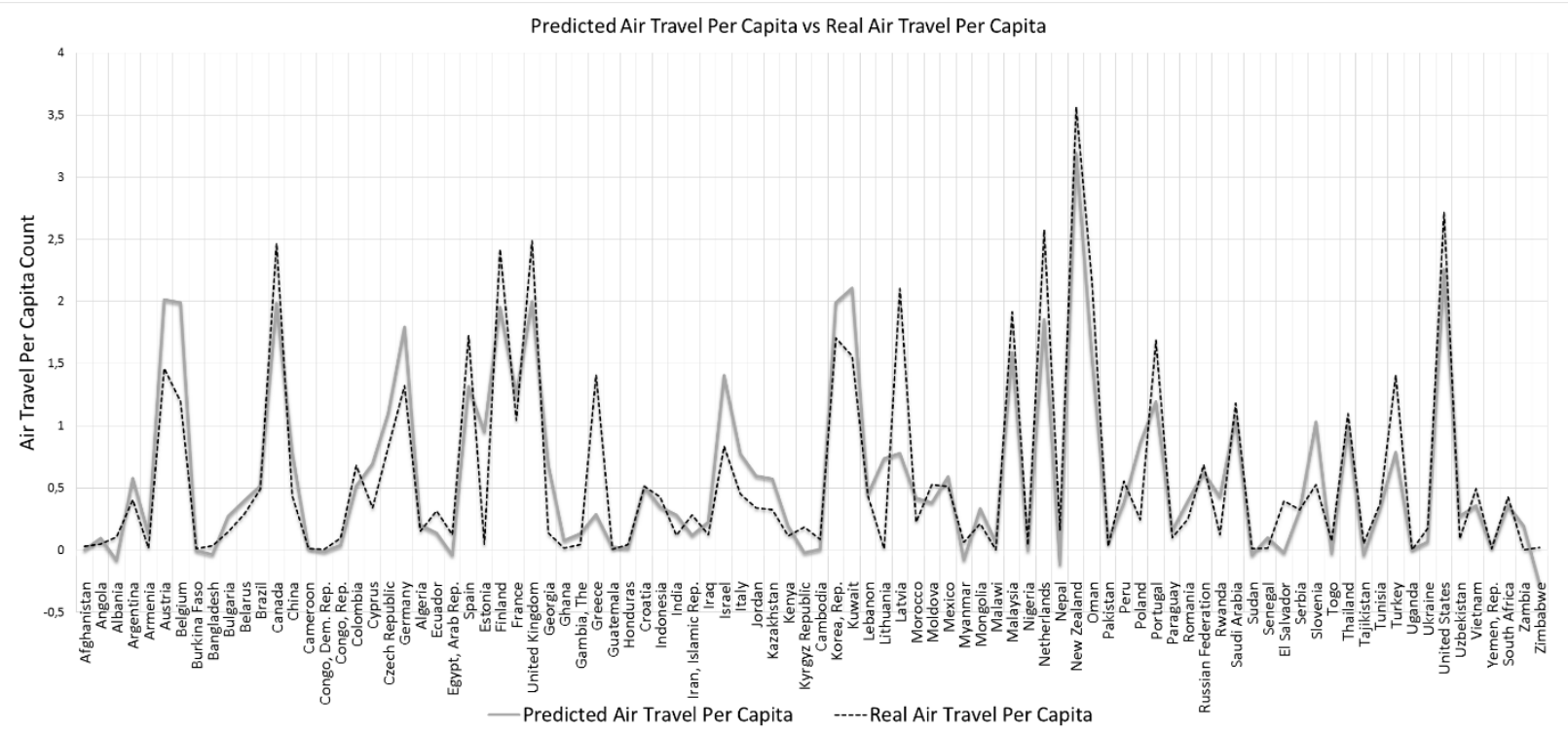

\subsection{Measuring the Weights of Features}

Since polynomial normalization is applied to the data of some features, the weights of the coefficients cannot be determined by proportioning the coefficients in the regression model. For this reason, for each feature, all input data was entered into the regression model again by increasing the feature values by $10 \%$, and how much the results changed compared to the previous prediction was examined.

Figure 5: Regression Model Predictions after Feature Value Set Increased One by One

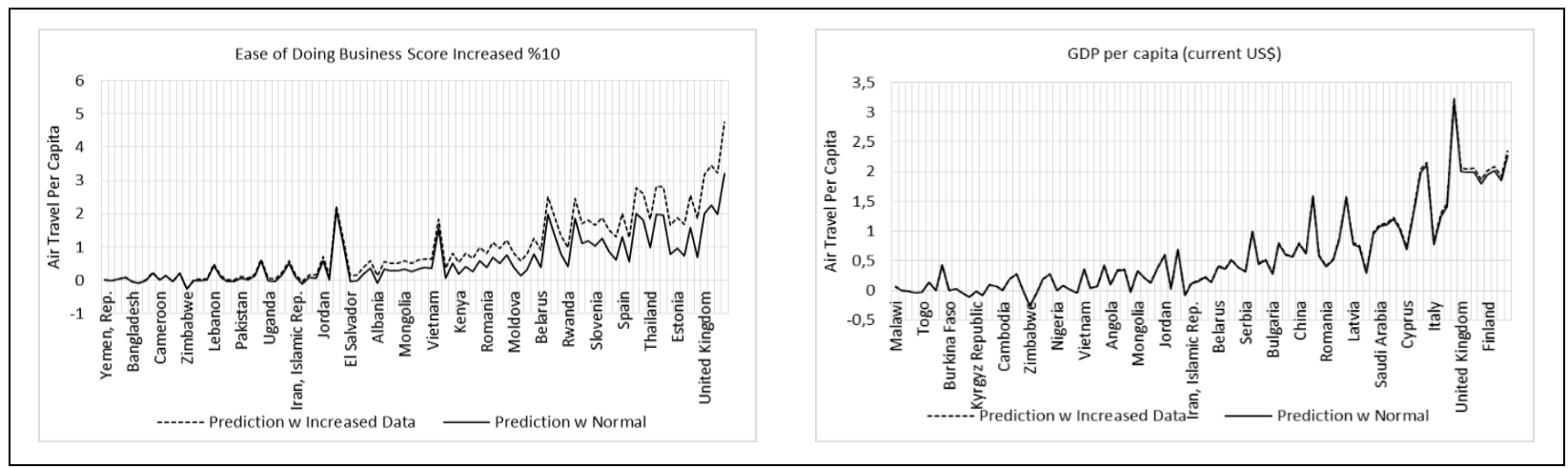




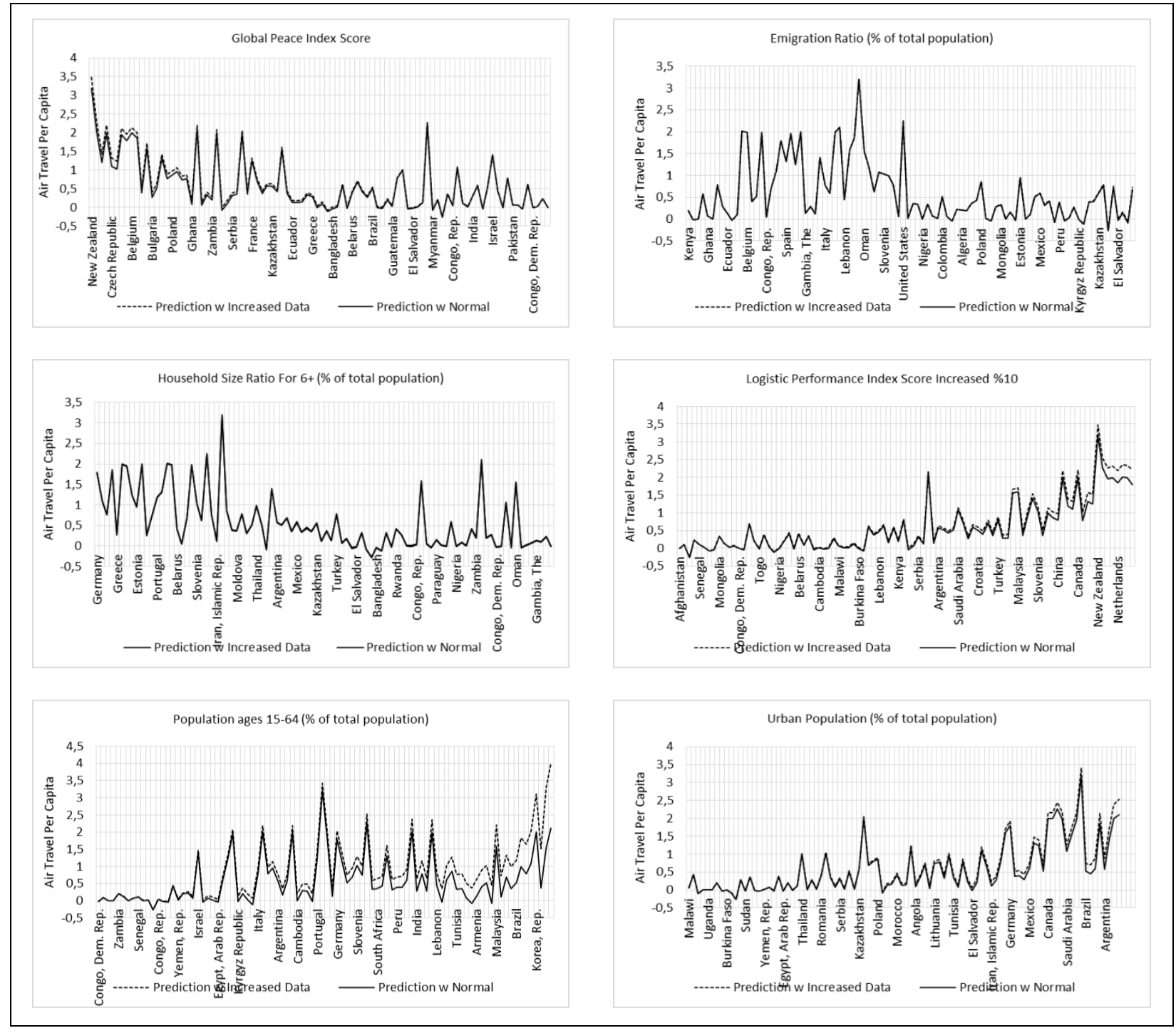

In Figure 5, the countries for each feature are ordered with their feature values from small to large. Also, it is seen that the increase of air travel per capita values for some features are exponential, such as Ease of Doing Business Score, Logistic Performance Index Score, Population Ages 15-64, Urban Population and GDP per Capita. Table 5 is generated by taking the averages of Figure 5 feature prediction differences and it is clearly seen that according to the regression model Ease of Doing Business and Population Ages 15-64 features are stronger than others. Detailed findings are shared in Section 4.

Table 5: Air Travel per Capita Change Rates with Feature Value Increase by $10 \%$

\begin{tabular}{lcc}
\hline Feature Name & $\begin{array}{c}\text { Average Air Travel Per Capita } \\
\text { Prediction Changes of Countries }\end{array}$ & $\begin{array}{c}\text { Normalized } \\
\text { Weight }\end{array}$ \\
\hline Ease of Doing Business Score & $34,92 \%$ & $31,2 \%$ \\
\hline GDP Per Capita (current US\$) & $1,55 \%$ & $1,4 \%$ \\
\hline Global Peace Index Score & $8,5 \%$ & $7,7 \%$ \\
\hline Emigration Ratio (\% of total population) & $1,14 \%$ & $1,0 \%$ \\
\hline Household Size Ratio For 6+ & $\mathbf{- 3 , 2 6 \%}$ & $2,9 \%$ \\
\hline
\end{tabular}




\begin{tabular}{lcc}
\hline Logistic Performance Index & $9,03 \%$ & $8,1 \%$ \\
\hline Population Ages 15-64 (\% of total population) & $43,78 \%$ & $39,2 \%$ \\
\hline Urban population (\% of total population) & $9,42 \%$ & $8,5 \%$ \\
\hline
\end{tabular}

\section{FINDINGS AND DISCUSSIONS}

First, it was observed that some of the 15 features that were detected by searching different resources had a very weak correlation with Air Travel per Capita. For example, Education Index Score, Neighbor Count, Emigration Ratio. These features were not used by the model as expected, but Population Ages 15-64 with poor correlation was used with high weight. The proportion of the compatible age group compatible with travel in the population could have strong effect on the result however according to the model this feature is the key aspect of aviation development. Therefore, the model can be considered failing for this feature. Also, some features with a high linear correlation like Gender Inequality Index, Visa Free Destination Count, and Global Weight of Cross Border Financial Services per Capita, IDI Index Score are not used by the regression model. This does not mean these features are not affecting aviation development in countries because they are just overshadowed by other features. Moreover, there were also some features selected by the model, even if they did not have a very strong linear correlation, for example, Urban Population, Percentage of International Migrants, Household Size Structure 6+. Probably, the reason is the independence structure of them so other features couldn't neutralize these features.

Another important finding is the countries that the regression model sees as outliers, Ireland, Switzerland, UAE, Qatar, and Denmark, Belgium, Estonia, Greece, Lithuania, Latvia, Netherlands. As mentioned in the above sections, the adjusted R Square of the regression model is 0,845 , so the regression model still needs some independent features. It may be useful to focus on the common characteristics of outlier countries to take the study to a further level.

In this study, 1 out of 15 features affects the model in the opposite direction of what was expected: Household Size Ratio For 6+ (\% of the total population). Normally, if the proportion of families with more than 6 people increases in a country, it is expected poverty to increase and the number of flights to decrease. However, in the regression model, that feature is affecting results in other directions. Probably, the regression model considered this feature as the increasing number of young people who can travel.

As mentioned in the Literature Review section, in research, the correlation between GDP and Air Travel Count measured above 0.9 (Ishutkina and Hansman, 2011) for the entire world between the years 1970 and 2005. However, in this study, it is seen that there is not such a correlation between GDP and Air Travel. This shows us that GDP and Aviation developments are increasing over the years due to different features.

Power of Ease of Doing Business on the development of aviation can be seen in Table 5. The reason is; the fact that the subevaluation criteria that make up the Ease of Doing Business index indirectly measure the welfare level in that country, the state of domestic peace, technological development, and the relations of countries with their neighbors. Therefore, this feature constitutes an important part of the model on its own.

\section{CONCLUSION}

Aviation has been battling the devastating impact of the Covid-19 outbreak since the beginning of 2019. Now, the importance of every passenger, the value of the money spent on investments and impact of airport efficiencies have increased to a level which is never touched before.

This study was carried out to enrich the research conducted before investments in the aviation industry. Countries or institutions that want to build new airports or want to expand their airports can use this study to predict the number of passengers in the coming years. In addition, countries that want to increase the number of passengers can examine this study and make inferences about which issues they should focus on first. Although the regression model has been created with only 8 features, examined other features can also be evaluated by investment analysts.

There are many continuation studies that can be done to increase the depth of this study. Country data of other previous years can also be used in model training, so that this study, which is carried out using only 2018 data, can be based on more solid foundations. In addition, by examining outlier countries, the model can be strengthened with new features for the points where the model is missing. Finally, the index type used in the model can be divided into social factors components and inserted into the model. Thus, it can be determined at which points the features overshadow each other. 


\section{REFERENCES}

Arvis, J. F., Ojala, L., Wiederer, C., Shepherd, B., Raj, A., Dairabayeva, K., \& Kiiski, T. (2018). Connecting to compete 2018: trade logistics in the global economy. World Bank.

Ayanso, A., Cho, D. I., \& Lertwachara, K. (2011). ICT development index and the digital divide. In International conference on information resources management (CONF-IRM 2011) proceedings, Seoul, South Korea. Retrieved from http://aisel. aisnet. org/confirm2011/3.

Bangwayo-Skeete, P. F., \& Skeete, R. W. (2017). Who travels visa-free? Insights into tourist hassle-free travel. Journal of Travel Research, 56(3), 407-418.

Calhoun, K. J., Teng, J. T., \& Cheon, M. J. (2002). Impact of national culture on information technology usage behaviour: an exploratory study of decision making in Korea and the USA. Behaviour \& Information Technology, 21(4), 293-302.

Chen, Z. (2018). A Comparison of Short-and Long-Haul Vacation Tourists on Evaluation of Attractiveness: The Case of Hong Kong. World Academy of Science, Engineering and Technology, International Journal of Humanities and Social Sciences, 5(2).

Cook, A. J., Kluge, U., Paul, A., \& Cristóbal, S. (2017, February). Factors influencing European passenger demand for air transport. In Air Transport Research Society World Conference. Air Transport Research Society.

Corcoran, A., \& Gillanders, R. (2015). Foreign direct investment and the ease of doing business. Review of World Economics, $151(1), 103-126$.

Curley, A., Dichter, A., Krishnan, V., Riedel, R., \& Saxon, S. (2020). Coronavirus: Airlines brace for severe turbulence.

Dębski, M., \& Nasierowski, W. (2017). Criteria for the selection of tourism destinations by students from different countries. Foundations of Management, 9(1), 317-330.

Gaye, A., Klugman, J., Kovacevic, M., Twigg, S., \& Zambrano, E. (2010). Measuring key disparities in human development: The gender inequality index. Human development research paper, 46, 1-37.

Gössling, S., Scott, D., \& Hall, C. M. (2020). Pandemics, tourism and global change: a rapid assessment of COVID-19. Journal of Sustainable Tourism, 29(1), 1-20.

Gudmundsson, S. V., Cattaneo, M., \& Redondi, R. (2021). Forecasting temporal world recovery in air transport markets in the presence of large economic shocks: The case of COVID-19. Journal of Air Transport Management, 91, 102007.

Hassan, Z., \& Basit, A. (2018). Ease of doing business and its impact on inward FDI. Hossain, MT, Hassan, Z., Shafiq, S., \& Basit, A.(2018). Ease of Doing Business and Its Impact on Inward FDI. Indonesian Journal of Management and Business Economics, 1(1), 52-65.

Index, G. P. (2018). Measuring peace in a complex world. Institute for Economics \& Peace.

Ishutkina, M. A., \& Hansman, R. J. (2011). Analysis of the interaction between air transportation and economic activity: a worldwide perspective.

İslamoğlu, E., YILDIRIMALP, S., \& Benli, A. (2014). Türkiye'de tersine göç ve tersine göçü teşvik eden uygulamalar: İstanbul ili örneği. Sakarya iktisat Dergisi, 3(1), 68-93.

Kwan, M. P., Dijst, M. J., \& Schwanen, T. (2007). The interaction between ICT and human activity-travel behavior. Transportation research. Part A, policy and practice, 41(2), 121-124.

Nguefack-Tsague, G., Klasen, S., \& Zucchini, W. (2011). On weighting the components of the human development index: a statistical justification. Journal of Human development and Capabilities, 12(2), 183-202.

Oxley, D. IATA, 2018, pp. 1-4, AIR PASSENGER MARKET ANALYSIS.

Özpolat, V. (2012). Küreselleşme sürecinde yurt dışındaki Türklerin önemi. Dumlupınar Üniversitesi Sosyal Bilimler Dergisi, (34), 211-219.

Schafer, A., \& Victor, D. G. (2000). The future mobility of the world population. Transportation Research Part A: Policy and Practice, 34(3), 171205.

Serrano, F., \& Kazda, A. (2020). The future of airport post COVID-19. Journal of Air Transport Management, 89, 101900.

Silvey, R. (2006). Consuming the transnational family: Indonesian migrant domestic workers to Saudi Arabia. Global networks, 6(1), 23-40.

Tabares, D. A. (2021). An airport operations proposal for a pandemic-free air travel. Journal of Air Transport Management, $90,101943$.

Tayco, R. (2013). Tourist arrivals and peace indices: Ascertaining the impact of the irregularities and ruggedness of peace situation on tourism across the globe. NORSU. Prism, 18(1). 
Taylor, J. E. (2006, June). International migration and economic development. In International symposium on international migration and development (pp. 28-30).

Woolman, D. C. (2001). Educational reconstruction and post-colonial curriculum development: A comparative study of four African countries. International Education Journal, 2(5), 27-46.

World Bank. (2017). Doing business 2018: reforming to create jobs. The World Bank.

Zheng, S., Duan, L., \& Sun, W. (2020). Global air network and cross-border venture capital mobility. Habitat International, 106, 102105. 